\title{
Phytotoxicity of Filtrate Extracts of Fungal Pathogens on Selected Tomato (Solanum lycopersicum L.) Cultivars
}

\author{
G.F. Akomolafe ${ }^{1 *}$, T.P. Terna ${ }^{1}$, A. Ubhenin ${ }^{2}$ and J. Abok ${ }^{3}$ \\ ${ }^{1}$ Department of Botany, Federal University Lafia, PMB 146, Lafia, Nasarawa State, Nigeria \\ ${ }^{2}$ Department of Biochemistry, Federal University Lafia, PMB 146 Lafia, Nasarawa State, Nigeria \\ ${ }^{3}$ Department of Chemistry, Federal University Lafia, PMB 146 Lafia, Nasarawa State, Nigeria
}

\begin{abstract}
The phytotoxic effect of culture filtrates of selected fungal pathogens on the morphology and anatomy of different tomato cultivars was evaluated in this study. Four tomato cultivars namely; Roma Savanna, Riogrande, Roma VF and Tropimech were treated with 21 days old culture filtrates of fungal pathogens namely; Alternaria triglochinicola, Aureobasidium pullulans, Pythium ultimum and Sclerotium rolfsii grown on Potato Sucrose Broth (PSB). These fungal filtrates were extracted using water, dichloromethane (DCM) and ethylacetate (EA). Healthy leaves excised from two months old tomato plants were inoculated by dipping their petioles in $20 \mathrm{ml}$ of each fungal filtrate for 3 days and observed for the appearance of disease symptoms. A. pullulans accounted for the highest necrotic and chlorotic leaf tissue area on all the studied tomato cultivars. The aqueous extracts were more biologically active, inducing the highest occurrence of mean total leaf necrosis (14.69\%) and chlorosis (57.21\%), compared to ethyl acetate (6.04\% necrosis and 7.03\% chlorosis) and dichloromethane $(6.57 \%$ necrosis and $4.02 \%$ chlorosis). Filtrate extracts of A. pullulans showed significantly higher negative effect $(\mathrm{P} \leq \mathrm{0.05})$ on anatomical features such as the thickness of epidermis, cortex and diameter of the vascular bundle of all the tomato cultivars. Further isolation and identification of phytotoxic compounds synthesized by the studied fungi are required for a better understanding of their mechanisms of disease initiation and yield reduction.
\end{abstract}

Keywords: anatomy; Aureobasidium pullulans; fungi extracts; pathogenicity; tomato

\section{INTRODUCTION}

Fungi of different genera have been reported to produce toxic metabolites (mycotoxins) which can reduce the viability of seeds, disrupt growth processes and development of plant organs (Caster \& Frederiksen 1980; Gopinath \& Shetty 1988). A lot of environmental stresses including drought, salinity, heavy metals and even pathogenic fungi attacks have been reported to have direct effects on morphology, anatomy and physiology of plants (Xu et al., 2008; Chen et al., 2014).

Anatomical changes occur in plants as a result of exposure to environmental stress conditions. Anatomical changes in stomata properties, the thickness of mesophyll, storage tissues and vascular tissues could be developed as means of surviving such stress conditions (Vasellati et al., 2001; Pengelly et al., 2010; Pereira et al., 2011; Ribeiro et al., 2012). Plants have developed a series of physiological responses to attack by fungal pathogens. One of such responses is the prevention of entrance of the pathogens by closing their stomata. Therefore the properties of stomata in the leaves are indications of plants' adaptive responses to pathogens (Gudesblat et al., 2009; Zeng et al., 2010). This study was therefore aimed at investigating the anatomical and morphological modifications of some commonly grown tomato cultivars, in response to infection by pathogenicityrelated metabolites of some fungal pathogens. The findings of this study shall enhance ongoing efforts towards the selection of disease resistant and higher yielding tomato cultivars in the study area and beyond. 


\section{MATERIALS AND METHODS}

\section{A. Source of Fungal Isolates and Tomato Cultivars}

Fungal pathogens of tomato used in the study namely; Alternaria triglochinicola, Aureobasidium pullulans, Pythium ultimum and Sclerotium rolfsii, were collected from the culture bank of the Plant Pathology unit of the Department of Botany, Federal University Lafia, and maintained on Potato Dextrose Agar (PDA) slants at $28^{\circ} \mathrm{C}$ prior to pathogenicity studies.

Seeds of tomato cultivars used in the study, namely Roma Savanna, Riogrande, Roma VF and Tropimech were extracted from healthy tomato fruits bought from the tomato market in Gboko, Benue State, Nigeria.

\section{B. Production of Phytotoxic Secondary Metabolites}

The methods of Zheng et al. (2010) were used as follows:

Ten $6 \mathrm{~cm}$ diameter mycelia plugs were obtained from actively growing regions of 7 days old cultures of the selected pathogenic fungi on Potato Dextrose Agar (PDA) and transferred into $900 \mathrm{ml}$ flasks containing $500 \mathrm{ml}$ of Potato Sucrose Broth (PSB) (Potato infusion - 200g; Sucrose - 20g; Water - 1L), and incubated at ambient temperature $\left(28^{\circ} \mathrm{C} \pm 2^{\circ} \mathrm{C}\right)$ for 21 days. Cell-free culture filtrates were obtained by passing the liquid through four layers of cheesecloth and Whatman no. 1 filter paper. A total of 150 glass flasks were used, 30 for each fungus and a total volume of $75 \mathrm{~L}$ of $\mathrm{PSB}$ at the rate of $15 \mathrm{~L}$ per isolate were used.

\section{Leaf Bioassay}

Healthy tomato leaves obtained from 2 months old tomato plants were excised using a sterile scalpel and conveyed in sterile polyethylene bags to the Botany Laboratory of Federal University Lafia. Excised tomato leaves were placed in sterile petri dishes at the rate of 2 leaves per plate. The petioles of the leaves were wrapped in sterile cotton balls and separately moistened with $20 \mathrm{ml}$ of each fungal filtrate. Healthy leaves moistened with sterile tap water served as the control treatment. The experimental units comprised of 4 fungi, 4 tomato cultivars, and three replicates $(5 \times 4 \times 3)$. The experiment was monitored for three days after. On the fourth day, the morphological and anatomical assessments were carried out.

\section{Extraction and Bioassay of Phytotoxic Compounds from Culture Filtrates of Pathogenic Fungi}

The liquid to liquid extraction technique was used as reported by Vikrant et al. (2006) with minor modifications. Four hundred millilitres (400ml of dichloromethane, followed by $400 \mathrm{ml}$ of ethyl acetate respectively were gently agitated in about $400 \mathrm{ml}$ of crude toxin filtrates in a separatory funnel and allowed to stand for 20 minutes. Both aqueous and solvent fractions were evaporated to dryness at $75^{\circ} \mathrm{C}$ to concentrate the extract using a Laborata $400 \mathrm{~L}$ rotary evaporator at $160 \mathrm{rpm}$. The residues were dissolved in $40 \mathrm{ml}$ of sterile distilled water, and their toxicity measured using the leaf necrosis assay earlier reported. Plant materials treated with sterile distilled water served as controls.

\section{E. Anatomical Studies}

Studies on the effect of filtrate extracts of fungal pathogens on the leaf anatomy of infected tomato plants were carried out following the methods of Oloyede et al. (2011) as follows: Sizeable portions of fresh matured leaves of tomatoes treated with each fungal filtrate were cut from the standard median positions. The leaves were decolourized by boiling in $70 \%$ ethanol at $60^{\circ} \mathrm{C}$ for about 10 minutes. They were washed carefully with water to remove all the traces of alcohol. These were boiled in $2 \%$ sodium hydroxide solution for about 5 minutes. The partially cleared leaves were then cleared by soaking them in Petri dishes containing $2 \%$ of domestic bleach (Sodium hypochlorite). The completely cleared leaves were rinsed with water to get rid of the bleach to preserve the cells of the leaves. The specimens were stained with Safranin O, placed on a clean glass slide in $25 \%$ glycerol, covered with a clean cover slip and mounted on a digital compound photomicroscope for examination.

The guard cell area was calculated using the following equation: 


$$
\text { Guard cell area }=\text { length } \times \text { width } \times k\left(\mathrm{~mm}^{2}\right)
$$

Where $k$ (Franco's constant $)=0.78524$

Free-hand fresh transverse sections of the petioles of the leaves of each treatment were made following the methods of Akomolafe et al. (2017). Two or three drops of $1 \%$ Safranin O stain were transferred by pipette to clean slide. The specimen was then placed by forceps to the drop of stain and left for one to two minutes. The stain was rinsed with distilled water, and the stained specimens were transferred to clean slides. They were covered with clean coverslips. The coverslips were sealed with transparent nail polish. The mounted specimen was then placed on the digital compound photomicroscope for microscopic observation.

\section{F. Measurement of Parameters}

For the determination of leaf necrosis and yellowing, the area of the leaf affected was estimated, and the percentage was calculated with reference to the total area of the leaf blade. The anatomical parameters including intervenal distance, stomata frequency, area of guard cells, the thickness of the epidermis, the thickness of the cortex, the diameter of vascular bundles, the number of trichomes, length of trichomes and number of subsidiary / epidermal cells were determined in all the treatments. The counting and measurements were carried out using ten fields of view of the microscope in three replicates, thereby making 30 counts/measurements per parameter for each treatment. The digital compound microscope was properly calibrated using a scanned metric ruler and ToupView image software version 3.7 was used for measurements of all the parameters.

\section{G. Experimental Design and Statistical analysis}

All experimental units were laid out in a Completely Randomized Design (CRD). Quantitative data obtained were subjected to Analysis of Variance (ANOVA). Significant means were separated by Duncan Multiple Range Test (DMRT) at 5\% level of probability using SPSS software version 22 .

\section{RESULTS}

\section{A. Pathogenicity of different fungi extracts on Tomato cultivars}

Extracts obtained from culture filtrates of assayed fungal pathogens using different solvents differed in their pathogenicity on tested tomato cultivars. Aqueous extracts of A. pullulans yielded the highest occurrence of leaf necrosis on the Roma Savanna (32.00\%) and Tropimech (20.00\%) tomato cultivars (Figure 1). Ethyl acetate extracts of $A$. pullulans induced the highest occurrence of leaf necrosis (40.00\%) on the Riogrande cultivar, while aqueous extracts of $A$. triglochinicola were most necrotic on leaves of the Roma VF cultivar. The highest occurrences of leaf yellowing (100.00\%) were observed in all tested tomato cultivars when aqueous extracts of $A$. pullulans were inoculated on healthy leaves of tomato plants (Figure 2). Differences in the effect of different solvent fractions of fungal filtrates on evaluated tomato cultivars were significant $(\mathrm{P} \leq 0.05)$.

Aqueous extracts of culture filtrates of the assayed pathogenic fungi were the most biologically active (Table 1), yielding the highest and significantly different $(\mathrm{P} \leq 0.05)$ mean total leaf necrosis (14.69\%) and leaf yellowing (57.21\%) compared to extracts obtained using dichloromethane $(6.57 \%$ leaf necrosis and $4.02 \%$ chlorosis) and ethyl acetate (6.04\% leaf necrosis and $7.03 \%$ chlorosis).

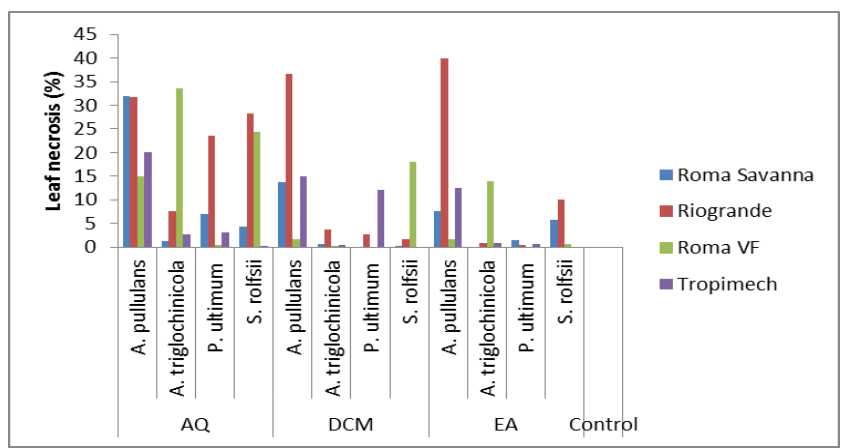

Figure 1. Necrosis effects of different extracts fractions of fungal filtrates on tested tomato cultivars 


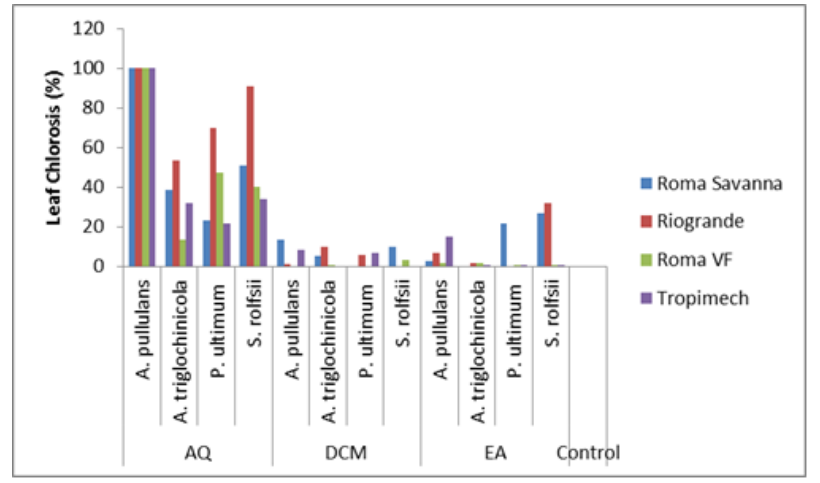

Figure 2. Chlorosis effects of different extracts fraction of fungal filtrates on tested tomato cultivar

Table 1. Overall effects of different extract fractions of fungal filtrates on tested tomato cultivars

\begin{tabular}{|l|c|c|}
\hline & \multicolumn{2}{|c|}{ Mean Total Disease Induced (\%) } \\
\hline Extract & Leaf Necrosis & Leaf Yellowing \\
\hline Aqueous & $14.69^{\mathrm{b}}$ & $57.21^{\mathrm{b}}$ \\
\hline Dichloromethane & $6.57^{\mathrm{a}}$ & $4.02^{\mathrm{a}}$ \\
\hline Ethyl Acetate & $6.04^{\mathrm{a}}$ & $7.03^{\mathrm{a}}$ \\
\hline
\end{tabular}

Means followed by the same superscript within the same column are not significantly different $(\mathrm{P} \leq 0.05)$

\section{B. Anatomical Effects of Different extracts of Fungal toxin on Roma Savanna cultivar}

The extracts of fungal culture filtrates obtained using different solvents had different anatomical effects on the Roma Savanna cultivar, with more significant effects observed in plant tissues inoculated with aqueous extracts compared to extracts obtained using other solvents (Figure 3). Excised leaf tissues of the Roma Savanna cultivar inoculated with aqueous extracts of $A$. pullulans showed the highest reductions in the thickness of both cortex (1.30mm) and epidermal layer $(0.15 \mathrm{~mm})$ as well as mean length of trichomes $(1.19 \mathrm{~mm})$. The least diameter of vascular bundles (1.90mm) was observed in leaf tissues inoculated with aqueous extracts of $P$. ultimum and dichloromethane extracts of $A$. pullulans, respectively. Aqueous extracts of $S$. rolfsii yielded the least stomatal frequency (5.67) guard cell area $\left(0.04 \mathrm{~m}^{2}\right)$, and number of subsidiary and epidermal cells (13.33) respectively. The least mean intervenal distance of leaf tissues of the Roma Savanna tomato cultivar $(1.17 \mathrm{~mm})$ was observed under the influence of dichloromethane extracts of $A$. pullulans. The differences in the effects of different solvent extracts on the anatomical features of the Roma Savanna tomato cultivar were significant $(\mathrm{P} \leq 0.05)$.

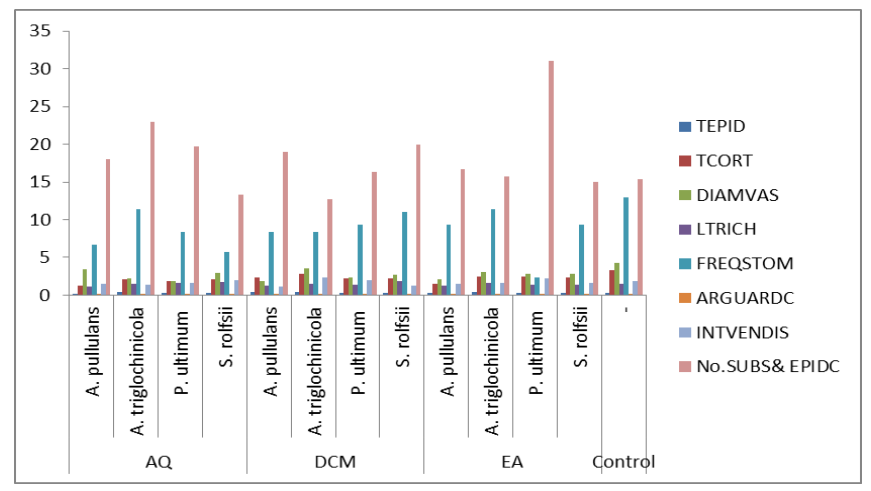

Figure 3. Anatomical effects of different filtrate extracts of fungal pathogens on the Roma Savanna tomato cultivar $\mathrm{AQ}=$ Aqueous

DCM = Dichloromethane

$\mathrm{EA}=$ Ethyl Acetate

TEPID $=$ Thickness of Epidermis

TCORT $=$ Thickness of Cortex

DIAMVAS = Diameter of Vascular Bundle

LTRICH = Length of Trichomes

ARGUARDC $=$ Area of Guard Cells

INTVENDIS $=$ Interveinal Distance

No. of SUBS. \& EPIDC = Number of Subsidiary and

Epidermal Cells

FREQSTOM = Frequency of Stomata
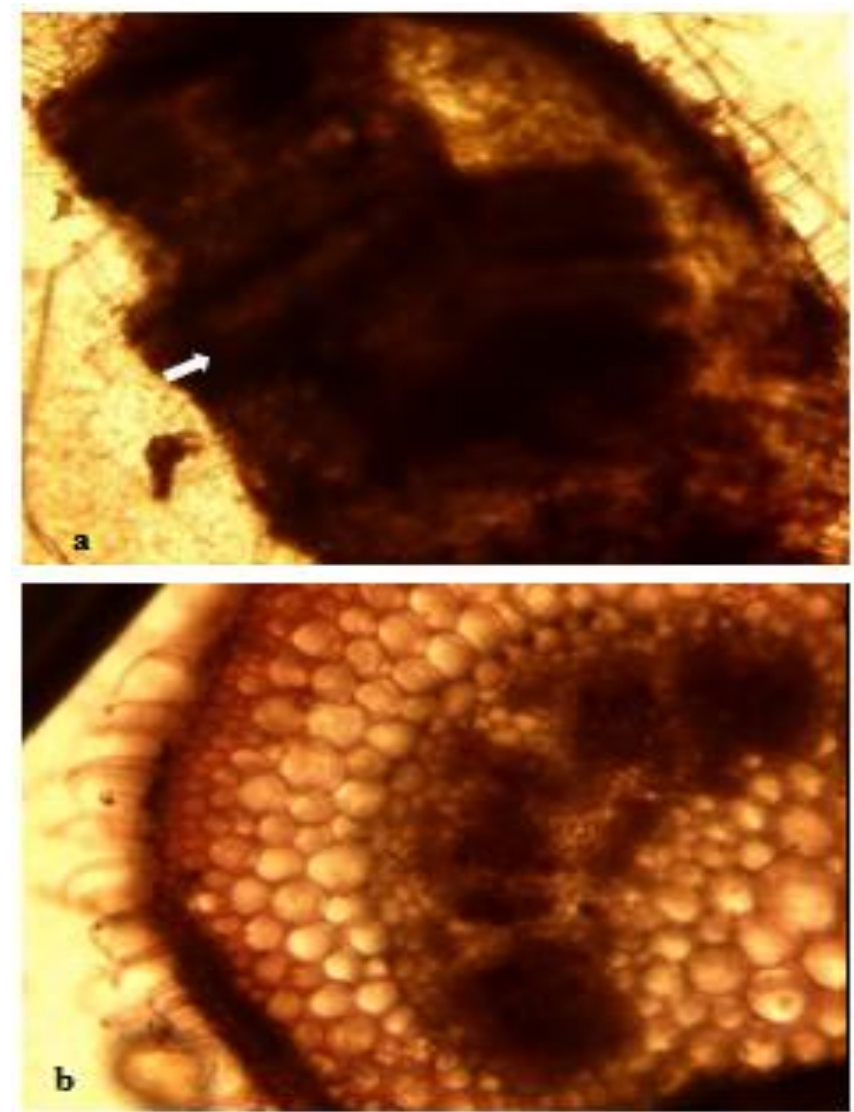
Plate 1. (a) Extensive degradation of vascular and cortical tissues of the Roma Savanna tomato cultivar inoculated with aqueous extracts of Aureobasidium pullulans culture filtrates; (b) Healthy tissues of the Roma Savanna cultivar in Control

\section{Anatomical Effects of Different Extracts of the Fungal Toxin on Riogrande Tomato Cultivar}

The effects of the different filtrates of fungal pathogens on the Riogrande tomato cultivar are presented in Figure 4. Excised leaves of the Riogrande cultivar exposed to aqueous extract of $P$. ultimum showed the least stomatal frequency (4.67), while exposure to aqueous extracts of $S$. rolfsii gave rise to leaf samples of the Riogrande cultivar with the least guard cell area $\left(0.04 \mathrm{~mm}^{2}\right)$ and mean number of subsidiary and epidermal cells (14.67). The least thickness of the epidermis $(0.22 \mathrm{~mm})$ and length of trichomes $(1.27 \mathrm{~mm})$ were observed when excised leaves of the Riogrande cultivar were challenged with dichloromethane extracts of $A$. pullulans. Leaf samples inoculated with ethyl acetate extracts of $A$. pullulans also showed the least thickness of cortex $(1.92 \mathrm{~mm})$ and diameter of vascular bundles $(2.21 \mathrm{~mm})$. The least intervenal distance $(0.91 \mathrm{~mm})$ was also observed in leaf samples of the Riogrande cultivar inoculated with ethyl acetate extracts of $A$. triglochinicola culture filtrates. Differences in anatomical effects of the different solvent extracts of culture filtrates of the assayed fungal pathogens on the Riogrande cultivar were significant $(\mathrm{P} \leq 0.05)$.

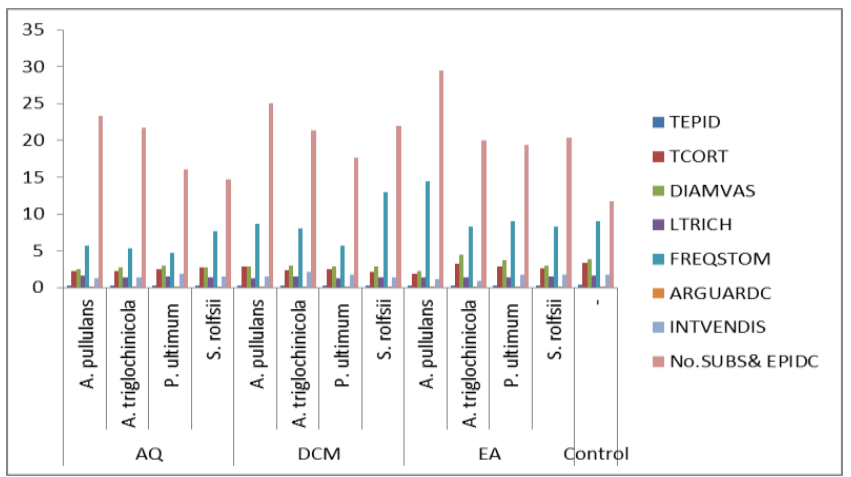

Figure 4. Anatomical effects of different filtrate extracts of fungal pathogens on the Riogrande tomato cultivar

$\mathrm{AQ}=$ Aqueous

DCM $=$ Dichloromethane
$\mathrm{EA}=$ Ethyl Acetate

TEPID $=$ Thickness of Epidermis

TCORT $=$ Thickness of Cortex

DIAMVAS $=$ Diameter of Vascular Bundle

LTRICH = Length of Trichomes

FREQSTOM = Frequency of Stomata

ARGUARDC $=$ Area of Guard Cells

INTVENDIS $=$ Interveinal Distance

No. of SUBS. \& EPIDC = Number of Subsidiary and Epidermal Cells

\section{Anatomical Effects of different extracts of the fungal toxin on Roma VF cultivar}

The different extracts obtained from culture filtrates of fungal pathogens differed in their anatomical effects on the Roma VF cultivar (Figure 5, Plate 2). Leaf tissues of the Roma VF tomato cultivar inoculated with aqueous extracts of $A$. pullulans showed the least thickness of the epidermis $(0.15 \mathrm{~mm})$, cortex $(1.67 \mathrm{~mm})$, length of trichomes $(1.21 \mathrm{~mm})$, frequency of stomata (5.67), and number of subsidiary and epidermal cells (17.67). The least guard cell area $\left(0.02 \mathrm{~mm}^{2}\right)$ was observed in plant tissues inoculated with aqueous extracts of $A$. triglochinicola. Ethyl acetate extracts yielded the least thickness of vascular bundles $(2.85 \mathrm{~mm})$, while dichloromethane extracts of $A$. pullulans gave the least mean intervenal distance $(1.34 \mathrm{~mm})$ in inoculated leaf tissues of the Roma VF tomato cultivar. Differences in anatomical effects of different extracts obtained from culture filtrates of fungal pathogens were significant $(\mathrm{P} \leq 0.05)$.

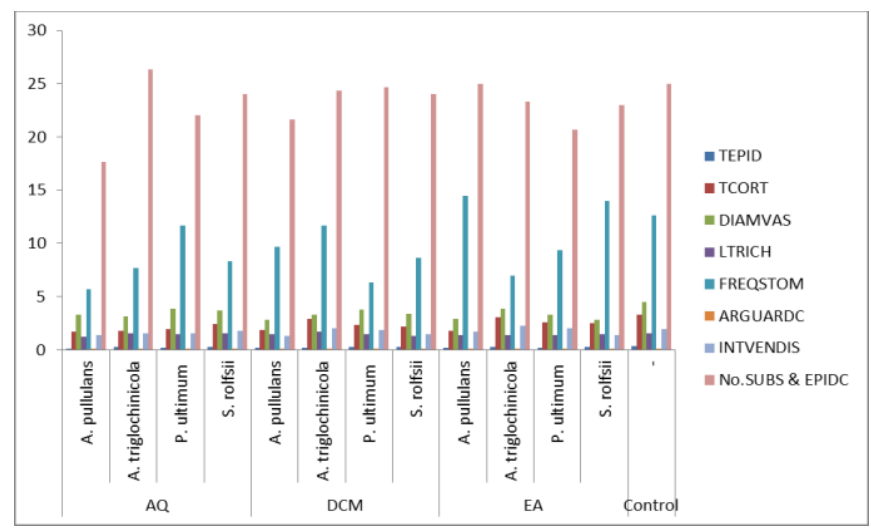

Figure 5. Anatomical effects of different filtrate extracts of fungal pathogens on the Roma VF tomato cultivar

$\mathrm{AQ}=$ Aqueous

DCM = Dichloromethane

$\mathrm{EA}=$ Ethyl Acetate

TEPID $=$ Thickness of Epidermis

TCORT $=$ Thickness of Cortex

No. of SUBS. \& EPIDC $=$ Number of Subsidiary and Epidermal Cells 
DIAMVAS $=$ Diameter of Vascular Bundle

LTRICH = Length of Trichomes

FREQSTOM = Frequency of Stomata

ARGUARDC $=$ Area of Guard Cells

INTVENDIS = Intervenal Distance
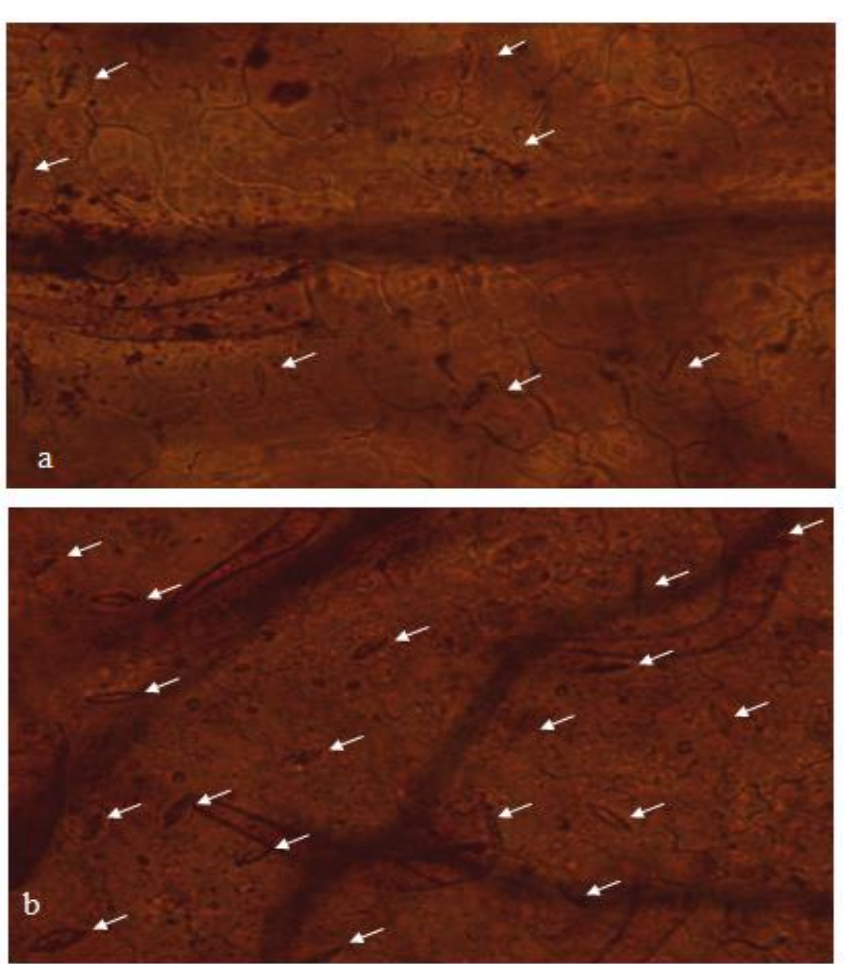

Plate 2. (a) Reduction in Stomatal Frequency in Leaf

Tissues of the Roma VF Cultivar Treated with Aqueous

Extracts Alternaria triglochinicola compared to (b) healthy controls

\section{E. Anatomical Effects of different extracts of the fungal toxin on Tropimech tomato} cultivar

The phytotoxic effects of different filtrate extracts of pathogenic fungi on the anatomy of the Tropimech tomato cultivar are presented in Figure 6. Plant tissues challenged with aqueous and ethyl acetate extracts of $A$. pullulans resulted in the least mean number of subsidiary and epidermal cells (18.00). Aqueous extracts of $A$. triglochinicola accounted for the least thickness of the epidermis $(0.17 \mathrm{~mm})$ and area of guard cells $\left(0.04 \mathrm{~mm}^{2}\right)$, while aqueous extracts of $S$. rolfsii resulted in the least thickness of cortex $(1.97 \mathrm{~mm})$ and diameter of vascular bundles $(2.17 \mathrm{~mm})$. Ethyl acetate extracts of $A$. pullulans accounted for the least stomatal frequency (6.67) and intervenal distance $(1.38 \mathrm{~mm})$, while the least mean length of trichomes $(1.16 \mathrm{~mm})$ was observed in Tropimech leaf tissues inoculated with ethyl acetate extracts of $P$. ultimum (Plate 3).

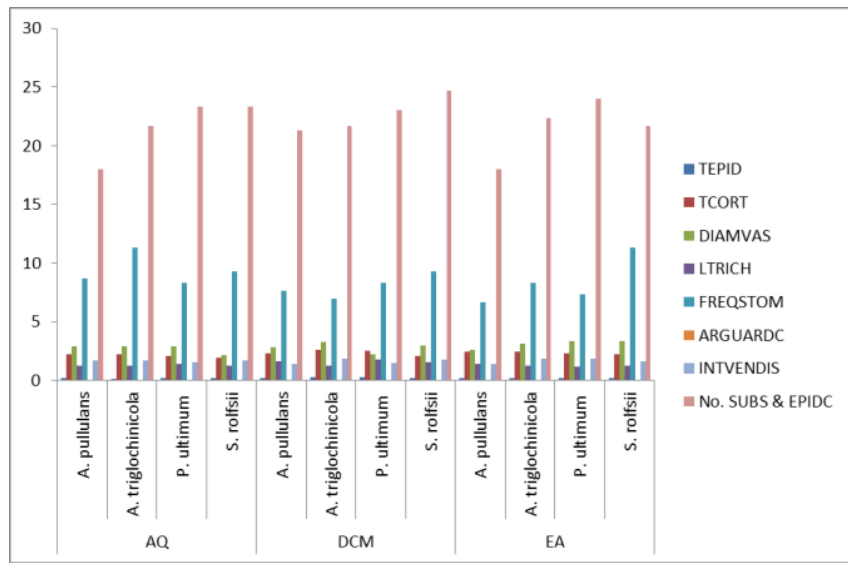

Figure 6. Anatomical effects of different filtrate extracts of fungal pathogens on the Tropimech tomato cultivar

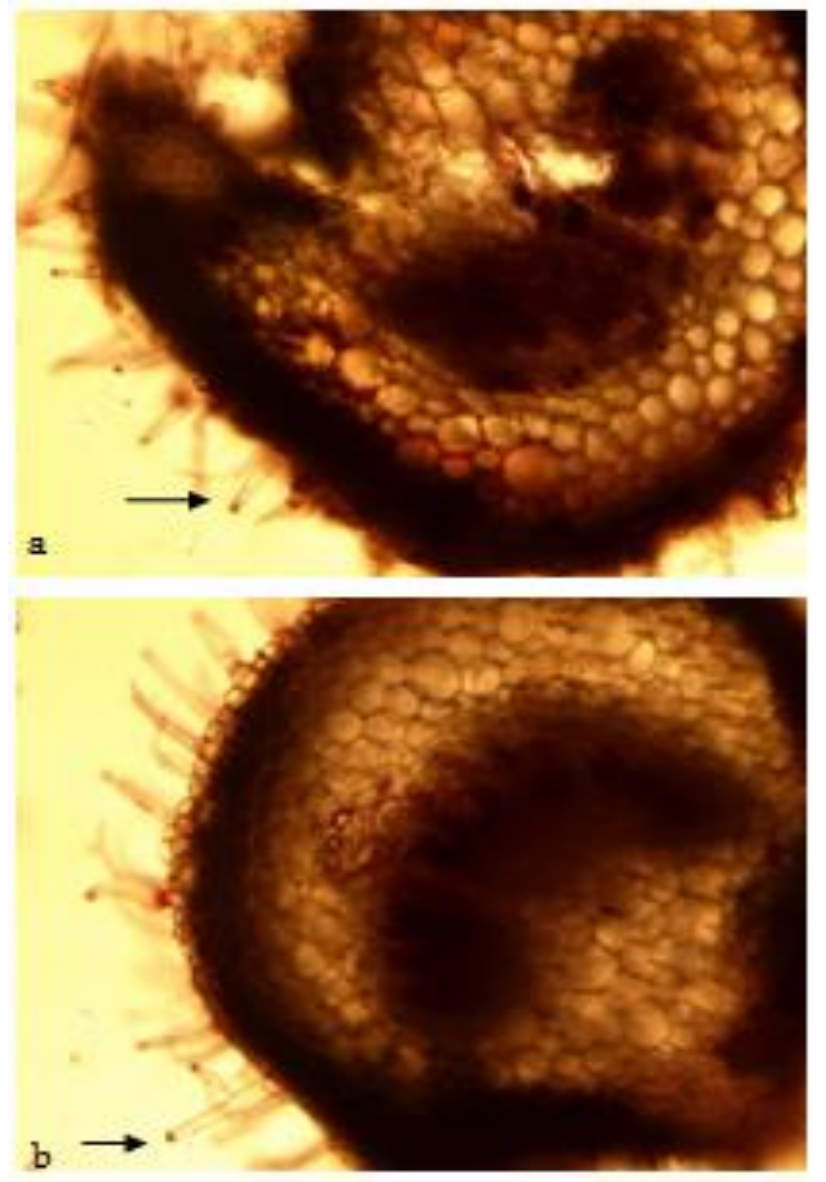

Plate 3. (a) Reduction in mean length of trichomes in petiole sections of the Tropimech cultivar treated with aqueous extracts of Pythium ultimum culture filtrates compared to (b) healthy controls. 


\section{DISCUSSION}

Adverse phytotoxic effects were observed on the anatomical features of all tomato cultivars treated with different extracts of fungal culture filtrates. Similarly, Mitsuya et al. (2000) reported that stress in plants as a result of either abiotic or biotic influences had been reported to trigger changes in the internal structure and functions of plant organs. The reduction in the thickness of epidermis, frequency of stomata and area of guard cells of these tomato cultivars under the influence of each of the filtrate extracts agrees with the findings of Garuba et al. (2014) in their study on the effects of fungal filtrates on Zea mays, in which it was reported that culture filtrates of Aspergillus niger and Penicillium chrysogenum significantly reduced the epidermal thickness and stomata sizes of Zea mays.

Tomato plants subjected to disease stress by filtrate extracts of pathogenic fungi in the reported study showed reductions in the thickness of the epidermis, the thickness of the cortex, vascular bundles, length of trichomes and number of subsidiary and epidermal cells. In a related study, Akomolafe et al. (2017) also reported reduced thickness of vascular bundles, epidermis and cortex in tomato plants under the stress of microgravity. Changes in number and length of trichomes by plants under environmental stress conditions have been described by Skaltsa et al. (1994) as means of plants protection from stressors.

Responses of plants to biotic and abiotic stress conditions differ according to their genetic composition. This explains why cultivars of plants exposed to the same environmental conditions respond differently and are corroborated by David et al. (2017) who reported varying anatomical responses of different wheat cultivars to drought stress. Furthermore, similar changes in properties of stomata such as stomata frequency, sunkenness of stomata and reduced area of guard cells observed in some of the tomato cultivars in the study have also been reported by Wright and Hiron (1969), and can be liked to transpiration regulatory mechanisms adopted by plants for survival under varying conditions of stress. The extensive tissue degradation observed in tomato plants challenged with culture filtrates of pathogenic fungi could be due to the activity of a cocktail of enzymes and toxins which degrade plant cell polymers, causing tissue disorganization for the release of carbon sources for their nutrition, as corroborated by the works of Mäkelä et al. (2014a) and Akpaninyang and Opara (2017).

Aqueous extracts of culture filtrates of assayed fungal pathogens were the most biologically active against the tested tomato cultivars. In a related study by Tanveer et al. (2012), it was reported that aqueous fractions of Euphorbia dracunculoides appeared more phytotoxic than organic fractions, suppressing chickpea germination, root and shoot length, as well as root and shoot dry weights of wheat and chickpea respectively. The significant biological activity of aqueous fractions of filtrate extracts observed in this study is an indication of the high polarity and hydrophilic of the phytotoxic components present. Variations in phytotoxicity of culture extracts of fungal pathogens as a result of differences in the polarity of extracting solvents have also been reported by Khan et al. (2004).

In the reported study, chromatographic fractions of fungal pathogens caused a substantial decline in chlorophyll content of inoculated tomato leaves. In a similar study by Meena et al. (2017), it was also reported that chromatographic fractions of Alternaria alternata obtained via bioassay-guided isolation induced significant chlorosis, necrosis and reduction in chlorophyll content on inoculated tomato leaves. A common response to pathogen infection is a reduction in the rate of photosynthesis in the infected leaves. Various plant pathogens are known to produce toxic metabolites, which may destroy the chloroplast resulting in the decrease of chlorophyll pigments. The reduction in chlorophyll content may also be as a result of the inhibition of chlorophyll synthesis by the biochemical activity of toxic metabolites synthesized by the fungal pathogens, as earlier suggested by Ammajamma and Patil (2008), also Prasad and Upadhyay (2010).

\section{CONCLUSION}

Results obtained from this study suggests that secondary metabolites synthesized by the studied fungi account for diverse morphological and anatomical disease alterations in infected plants. Further isolation and identification of phytotoxic compounds synthesized by the studied fungi are required for a better understanding of their mechanisms of disease initiation and yield reduction in the study area. 


\section{ACKNOWLEDGEMENTS}

We hereby acknowledge the Nigerian Tertiary Education Trust Fund (TETFund) for providing financial support and the Management of Federal University Lafia, Nigeria for creating enabling environment for the research.

\section{REFERENCES}

[1] Akomolafe, GF, Omojola, J, Joshua, ES, Adediwura, SC, Adesuji, ET, Odey, MO \& Labulo, AH 2017, 'Growth and Anatomical Responses of tomato (Lycopersicon esculentum) under Microgravity and Normal Gravity Conditions', International Journal of Biological, Biomolecular, Agricultural, Food and Biotechnological Engineering, vol. 11, no. 5, pp. 335-338.

[2] Caster, L \& Frederikson, RA 1980, 'Fusarium head blight, occurrence of effects on sorghum yield and grain characteristics in Texas', Journal of Plant Disease, vol. 64, pp. 1017-1017.

[3] Chen, J, Duan, B, Wang, M, Korpelainen, H \& Li, C 2014, 'Intra and inter-sexual competition of Populus cathayana under different watering regimes', Functional Ecology, vol. 28, no. 1, pp. $124-136$.

[4] David, OA, Osonubi, O, Olaiya, CO, Agbolade, JO, Ajiboye, AA, Komolafe, RJ, Chukwuma, DM \& Akomolafe, GF 2017, 'Anatomical Response of Wheat Cultivars to Drought Stress', Ife Journal of Science, vol. 19, no. 2, pp. 323-331.

[5] El-Sayed, EA, El-Sobky \& Desoky, EM 2017, 'Influence of Irrigation Interval, Bio and Mineral Fertilization and their Interactions on some Physiological, Anatomical Features and Productivity of Maize', Zagazig Journal of Agricultural Research, vol. 44, no. 1, pp. 23-40.

[6] Garuba, T, Abdulrahaman, AA, Olahan, GS, Abdulkareem, KA \& Amadi, JE 2014, 'Effects of Fungal Filtrates on Seed Germination and Leaf Anatomy of Maize Seedlings (Zea mays L., Poaceae)', Journal of Applied Science and Environmental Management, vol. 18, no. 4, pp.
$662-667$

[7] Gopinath, A \& Shetty, HS 1988, 'Role of Volatile Metabolites Produced by Seed-bornegrowth of Fusarium moniliforme', Geobios, vol. 15, pp. 10-13.

[8] Gudesblat, GE, Torres, PS \& Vojnov, AA 2009, 'Stomata and Pathogens: Warefare at the Gate', Plant Sig Behav, vol. 4, no. 12, pp. 1114-1116.

[9] Khan, IA, Alam, SS \& Jabbar A 2004, 'Purification of Phytotoxin From Culture Filtrates of Fusarium oxysporum f.sp. ciceris and Its Biological Effects on Chickpea', Pakistan Journal of Botany, vol. 36, no. 4, pp. 871-880.

[10] Mitsuya, S, Takeoka, Y \& Miyake, H 2000, 'Effect of sodium chloride on foliar ultrastructure of sweet potato (Ipomoea batatas Lamb.) plantlets grown under light and dark conditions in vitro', Journal of Plant Physiology, vol. 157, pp. 661-667.

[11] Oloyede, FA, Akomolafe, FG \& Oladipo, OT 2011, 'Comparative foliar Anatomical and Morphological studies of Nephrolepis biserrata and Nephrolepis undulata in Nigeria', Journal of Science and Technology (Ghana), vol. 31, no. 2, pp. 1-10.

[12] Pereira, FJ, Castro, EM, Oliveira, C, Pires, MF \& Pasqual, M 2011, 'Mecanismos anatômicos e fisiológicos de plantas de aguapé para a tolerância à contaminação por Arsênio', Planta Daninha, vol. 29, no. 2, pp. 259-267.

[13] Ribeiro, MNO, Carvalho, SP, Pereira, FJ \& Castro, EM 2012, 'Anatomia foliar de mandioca em função do potencial para tolerância à diferentes condições ambientais', Rev Ciência Agro, vol. 43, no. 2, pp. 354-361.

[14] Schulze, ED \& Hall, AE 1982, 'Stomata responses to 
water loss and $\mathrm{CO}_{2}$ assimilation rates in plants of contrasting environments', eds Lange OL, Nobel PS, Osmond CB, Ziegler H, in Encyclopedia of plant physiology, Physiological plant ecology, vol. 12B, Springer-Verlag, Berlin, pp. 181-230.

[15] Skaltsa, H, Verykokidou, E, Harvala, C, Krabourniotis, G \& Manetas, Y 1994, 'UVprotective potential and flavonoid content of leaf hairs of Quercus ilex', Phytochemistry, vol. 37, pp. 987-990.

[16] Tanveer, A, Jabbar, MK, Kahliq, A, Matloob, A, Abbas, RN \& Javaid, MM 2012, 'Allelopathic Effects of Aqueous and Organic Fractions of Euphorbia dracunculoides Lam. on Germination and Seedling Growth of Chickpea and Wheat', Chilean Journal of Agricultural Research, vol. 72, no. 4, pp. 495-500.

[17] Vasellati, V, Oesterheld, M, Medan, D \& Loreti, J 2001, 'Effects of flooding and drought on the anatomy of Paspalum dilatatum', Annals of Botany, vol. 88, no. 3, pp. 355-36o.

[18] Wright, STC \& Hiron, RWP 1969, 'Abscisic acid, the growth inhibitor-induced in detached wheat leaves by a period of wilting', Nat London, vol. 224, pp. $719-720$.

[19] Xu, X, Yang, F, Xiao, XW, Zhang, S, Korpelainen, $\mathrm{H} \& \mathrm{Li}, \mathrm{CY}$ 2008, 'Sex-specific responses of Populus cathayana to drought and elevated temperatures', Plant Cell Environment, vol. 31, no. 6, pp. 850-860.

[20] Zeng, W, Melotto, M \& He, SY 2010, 'Plant Stomata: A Checkpoint of Host Immunity and Pathogen Virulence', Curr. Opin. Biotechnol, vol. 21, no. 5, pp. 599-603. 